\title{
Study of Reduced Formation Damage due to Oil Well Drilling Mud by Barite and Gas Oil Additives
}

\section{Kapil Gaur}

Department of Biotechnology, Deenbandhu Choturam University of Science and Technology, Murthal, Sonepat, India

"Corresponding author: Kapil Gaur, Department of Biotechnology, Deenbandhu Choturam University of Science and Technology, Murthal, Sonepat, India, Tel: 8376837633; E-mail: djgaur007@gmail.com

Received date: February 24, 2015; Accepted date: February 26, 2015; Published date: March 06, 2015

Copyright: (c) 2014 Gaur K. This is an open-access article distributed under the terms of the Creative Commons Attribution License, which permits unrestricted use, distribution, and reproduction in any medium, provided the original author and source are credited.

\begin{abstract}
This analysis presents study of the impact of drilling muds on the oil reservoir rocks specifications, and also the interactions between the clay minerals existing within the formation with the drilling muds. For minimization and interference of formation harm ensuing from drilling muds, and formation minerals, drilling muds were ready in such some way that they give the muds that are used according to the daily mud report of the South Company. These muds are $\mathrm{H}_{2} \mathrm{O}$ mud, Ferrochrome Lignosulfonate (FcLs).

About a hundred core plugs were ready from seven wells and for 3 fields of the Zubair formation from depths of over (3000) meters. The core plugs were cut in size to regarding one in. (2.54 centimeters) diameter and 3 centimeters length. They were cleansed, dried, and so subjected to petrophysical tests that were (porosity, porousness, saturation, and pore size distribution by the capillary pressure), X-ray diffraction, and also the petrographical analyses. The results of the experimental work showed that the clay minerals in formation increase the formation harm, and reduce the oil permeability. Additionally, the results showed that the treatments of drilling muds might cut back formation impairment. This was accomplished through create bridging system with completely different barytes additions seventy, $140,200,280 \mathrm{lb} / \mathrm{bbl}$ to $\mathrm{H} 2 \mathrm{O}$ mud. This bridging system creates an efficient waterproofing of impervious filter cake, thereby inhibiting continual losses of little solids and dust filtrate into the formation. Finally, relationships for various oil permeability's are obtained for predicting harm in oil permeability's as a result of completely different drilling muds.
\end{abstract}

Keywords: Oil; Lubricant; Barite; Mud; Fuel

\section{Introduction}

Drilling operations perpetually expose a formation to drilling fluids, which can impair its productive capability. This reduction in productivity is termed formation harm. There are several vital main functions of drilling muds in oiler drilling engineering however the disadvantage of victimization drilling fluids is expounded to formation harm. The choice of appropriate mud kind for a given reservoir could also be essential. Most investigations proved the consequences of drilling muds on rock permeableness and formation harm owing to the choice of unsuitable mud. This may be owing to the interactions between the lubricant filtrate with the formation minerals in the producing horizons, and also the penetration of drilling mud particles into the formation that cause pore plugging of the porous media. The harm caused by filtrate penetration depends on the effectiveness of fluid loss control. The filtrate penetration could vary from few inches to many feet. Harm quantitative relation (permeability once harm divided by the initial unmarred porosity) for permeability of oil could vary from 0.3 to 1.0 looking on the sort of filtrate and kind of core material. Therefore, it's necessary to pick the correct lubricant, which have the simplest major functions for drilling operations, and minimize formation harm. So as to forestall formation fluids from coming into the borehole, the hydrostatic pressure of the mud column ought to be bigger than the formation pore pressure. Consequently, mud tends to invade the porous formations. When the distinction between hydrostatic pressure and pore pressure is high huge loss of mud into the formation doesn't typically occur, as a result of the mud solids area unit filtered out onto the wall of the opening, forming a cake of comparatively low porosity through that solely filtrate will pass. This analysis deals with the impact of mud filtrates and dirt particles on formation permeability and formation minerals. A rise in water saturation within the zone straightaway around the wellbore would cause loss of oil porosity. However, in such a system, much of this water is also removed by boring, that happens in clean pay sand. If filtration happens into unclean sands (sands that contain clay minerals), the clay swelling or different mechanisms may cause losses in oil porosity, that can't be overcame by boring.

The two principle factors, which govern the magnitude of productivity impairment caused by mud, are as follows:-

1. The depth of invasion of its filtrate into the reservoir.

2. The amount of damage (permeability loss) that it causes.

\section{Literature Survey}

Nowak, et al. [1] studied the impact of binary compound solutions; field-drilling mud filtrates, and mud particles on effective oil porousness of productive sand cores that were identified to be water sensitive. The tests indicated that the filtrates from muds of low salt content caused low recovery percentages of the first oil permeability.

Bertness [2] conferred laboratory and field knowledge to assist within the analysis of water damage to grease sands and to propose attainable clarification for the kinds harm to grease sands which are 
discovered. The reservoir water permeability of unclean sands is severely reduced if the sands are exposed to water.

Abrams, [3] studied the possibility to minimize solids invasion and formation damage by adding bridging material to the muds. This bridging material was chosen by matching its size to the formation rock pore sizes. The core face was drilled a $(0.25)$ inch diameter hole, following mud exposure and removal, and then measured original permeability as a function of depth of the hole for comparison. The rapid restoration of the original permeability with a perforation depth of only (0.11) inch to 90 percent of the original permeability for both exposures indicates the shallow depth of impairment. The experiments indicated that muds containing bridging material that meets the onethird rule for bridging, impair rock to depth less than one inch.

Muecke, [4] focused his study on determining the effects of three types of analyses on sandstone samples, Scanning Electron Microscope (SEM) examinations to determine particle size and shape, sieve analyses to determine the amounts of various sizes of particles present, and X-Ray Diffraction (XRD) to determine mineralogical content. A micro-model of porous media was used to simulate the porous matrix present in sandstone formations.

Sanner, et al. [5] conducted core study of five different rock types to investigate the return permeability and changes in irreducible water saturation (Swi), when exposed to filtrate from oil-based and waterbased drilling mud by Hassler cell. Results indicated that the oil-based filtrate contains sufficient oil wetting surfactants and emulsifiers to reverse the wet-ability of rock surfaces from water wet to oil wet. The oil wet rock surface in the low permeability matrix, reduced the effective oil permeability drastically. In the high permeability matrix, reduced the irreducible water saturation, resulting in an increase in the effective oil permeability.

Ismail, et al. [6] investigated the effect of solids concentration and filter media on fluid loss and permeability recovery of cores depending on some consideration before Glenn [7] and Abrams (3) related to use bridging material. $\mathrm{KCl}$-polymer muds of different barite concentration and different types of core were used to perform the tests. Filtration tests showed that fluid loss increased as solids concentration in the mud increased. Increasing the solids concentration in the mud appears to improve permeability recovery when the cores were back flushed. However, high spurt loss and poor permeability recovery were observed if muds containing polymer materials were used without the addition of solid particles.

Hayadavoudi, et al. [8] made a study to control formation damage caused by kaolinite clay minerals. Most, if not all, laboratory analysts, upon observing Kaolinite mineral in the pore space of the sidewall or conventional cores, conclude that the main cause of possible formation damage (decrease in permeability) could be attributed to the migration of fines within the pores. Petrophysical analysis showed that within this short period of contact time between the rock and fluid at $\mathrm{pH}$ approximately 10-12, the permeability of cores decreased considerably. Both field and laboratory coring and/or drilling any sand with a high Kaolinite content (greater than 5\%), the best conditions for controlling the formation damage were to keep the $\mathrm{pH}$ of all injection fluids in a buffered to control the filtrate to near zero in such sensitive formation.

Warren, et al. [9] used air particles for minimizing formation impairment in drilling fluid system. Air particles were used as the bridging particles to remedial formation damage. This treatment was applied in higher-pressure wells and give low-density muds.

\section{Discussions}

Several experiments are done to research the foremost dominant factors of formation harm by drilling muds. Completely different mud treatments are accustomed to examine the possibility of reducing its damaging result.

\section{Conclusions}

X-ray diffraction analyses for core samples at pay zones indicated clean fine grained arenaceous rock with traces of clay minerals (very low or pure zones (100\%) quartz), this gave low injury in these intervals when exposed to drilling muds and will not suffer any swelling because of the alternative intervals. Some of the pay zone intervals containing differing kinds and percentages of clay minerals like Illite and Montmorillonite, suffers swelling and spalling once exposed to drilling muds that cause formation injury. All the muds, that were used, have the flexibility to break the petrophysical properties of formation, however some additives to mud might scale back petrophysical properties. Fuel oil addition would generally cause reduction in mud filtrate as a result of the formation of rubberized mud cake on the face of the paper or on the face of core samples.

\section{References}

1. Nowak TJ, Krueger RF (1951) The Effect of Mud Filtrates and Mud Particles upon the Permeabilities of Cores Drill. Prod Prac: 164-181.

2. Bertness TA (1953) Observation of water damage to oil productivity Drill. Prod Prac: 287-299.

3. Abrams A (1977) Mud Design to Minimize Rock Impairment due to Particle Invasion. JPT: 586-592.

4. Muecke TW (1979) Formation Fines and Factors Controlling Their Movement in Porous Media. JPT: 144-150.

5. Sanner DO, Azar JJ (1994) Alteration of Reservoir Rock Wettability and Its Flow Properties Caused by Oil-Based and Water-Based Drilling Muds. SPE: 171-180.

6. Ismail AR, Peden JM (1994) The Effect of Solids Concentration and Formation Characteristics on Formation Damage and Permeability Recovery. SPE: 203-212.

7. Glenn EE, Slusser ML (1975) Factors Affecting Well Productivity- II. Drilling Fluid Particle Invasion into Porous Media. Trans AIME 210: 132-139.

8. Hayatdavoudi A, Ghalambor A (1996) Controlling Formation Damage Caused by Kaolinite Clay Minerals. Society of Petroleum Engineers, Louisiana.

9. Warren B, King K, Browne G, Mann C (2001) Preventing Formation Impairment with a MicronAire Drilling Fluid System. AADE :1-10. 